p-ISSN 2798-0499 e-ISSN 2798-0502

\title{
The Influence of Viral Marketing And Consumer Confidence Against Online Shopping Decisions for Accounting Students State University of Medan Stambuk 2018
}

\section{Pengaruh Viral Marketing Dan Kepercayaan Konsumen Terhadap Keputusan Belanja Online Pada Mahasiswa Akuntansi Universitas Negeri Medan Stambuk 2018}

\author{
Boy Sitompul1); Cristy Natalia Sembiring ${ }^{2}$ \\ 1)Study Program of Economic Education, Faculty of Economic, Universitas Negeri Medan \\ 2) Study Program of Accounting , Faculty of Economic, Universitas Negeri Medan \\ Email: ${ }^{1)}$ Boysitom@gmail.com; ${ }^{2)}$ Cristynataliaa26@gmail.com
}

\begin{abstract}
How to Cite:
Sitompul., B., Sembiring, N. C. (2021). The Influence of Viral Marketing And Consumer Confidence Against Online Shopping Decisions for Accounting Students State University of Medan Stambuk 2018. Jurnal Ekonomi Manajemen Akuntansi Dan Keuangan, 2(4). DOI: https://doi.org/10.53697/emak.v2i4

ARTICLE HISTORY

Received [13 September 2021]

Revised [28 September 2021]

Accepted [05 October 2021]

KEYWORDS

Objectives, Number of samples, Ferdinand Theory, Research Results

This is an open access article under the $C C-B Y$-SA license

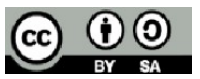

\section{ABSTRAK}

Tujuan dari penelitian ini adalah untuk mengetahui pengaruh viral marketing dan kepercayaan konsumen keputusan belanja di online shop pada mahasiswa Akuntansi Universitas Negeri Medan Stambuk 2018. Jumlah sampel dalam penelitian adalah 65 mahasiswa yang diperoleh dengan menggunakan perhitungan jumlah sampel teori Ferdinan. Hasil penelitian menunjukkan bahwa viral marketing (X1) dan Kepercayaan Konsumen (X2) secara masing-masing maupun secara bersamaan memiliki pengaruh terhadap pengambilan keputusan belanja online pada mahasiswa akuntansi.

\section{ABSTRACT}

The purpose of this study was to determine the effect of viral marketing and consumer confidence in online shopping decisions on Accounting students at the State University of Medan Stambuk 2018. The number of samples in the study was 65 students obtained by using the calculation of the number of samples of Ferdinand's theory. The results of the study show that viral marketing (X1) and Consumer Trust (X2), individually or simultaneously, have an influence on shopping decisions in online stores for accounting students.
\end{abstract}

\section{PENDAHULUAN}

Teknologi merupakan suatu jembatan yang dapat menghubungkan individu satu dengan indivdu lainnya tanpa terikat jarak dan waktu. Pesatnya perkembangan teknologi melahirkan revolusi dalam beberapa aspek salah satu diantaranya kegiatan perbelanjaan. Perpaduan kegiatan perbelanjaan dengan teknologi melahirkan suatu sistem yang disebut belanja online (online shop). Menurut Sari (2015:2018) online shop merupakan suatu proses transaksi secara tidak tatap muka antara penjual dan pembeli. Liang dan Lai (Harahap dan Dita,2018:196) mengemukakan pandangan yang berbeda dimana suatu transaksi yang menggunakan media internet disebut pembelian online.

Menurut data Badan Pusat Statistik (BPS) pada tahun 2020 terdapat 16.277 pelaku usaha belanja online dengan 51,97 persennya bergerak pada bidang usaha sektor perdagangan besar dan eceran, resparasi dan perawatan mobil dan sepeda motor. fenomena menarik muncul yaitu: 53,52 persen usaha langsung melakukan kegiatan belanja online saat baru mulai beroperasi, sebanyak 480 | Boy Sitompul, Cristy Natalia Sembiring; The Influence of Viral Marketing... 
16,96 persen usaha baru memulai kegiatan belanja online 1-2 tahun setelah beroperasi, dan 11 persen usaha baru mulai kegiatan belanja online 3-5 tahun setelah membuka kegiatan operasional usaha. Selain itu sebanyak $90 \%$ usaha melakukan menerima dan mengirim produk melalui media internet.

Perkembangan jumlah pemilik usaha online shop terlihat dari sebanyak $62 \%$ dimiliki oleh individu yang memiliki pendidikan SMA sederajat kebawah Jenis produk kebutuhan individu seperti pakaian, makanan dan minuman memberikan kontribusi paling banyak dalam transaksi secara online. Semakin berkembangnya suatu usaha maka memerlukan strategi pemasaran yang tepat untuk membuat konsumen mengambil suatu keputusan dalam belanja online. Terdapat beberapa faktor yang mempengaruhi keputusan konsumen, dua diantaranya yaitu viral marketing dan kepercayaan konsumen.

Viral marketing merupakan suatu strategi pemasaran berbasis digital dengan memiliki target konsumen yang sangat luas dalam membentuk suatu citra produk. Berdasarkan data Badan Statistik Telekomunikasi Indonesia menunjukkan bahwa sebanyak 73\% penduduk memiliki akses internet dalam rumah tangga. Berdasarkan hal tersebut dapat diketahui bahwa melalui strategi digital viral marketing dapat menjangkau lebih dari 50\% jumlah penduduk yang memiliki akses internet dalam rumah tangga. Selain sisi positif, viral marketing juga terdapat sisi negative dimana dapat mempengaruhi kepercayaan seorang konsumen. Kepercayaan merupakan titik pokok setiap individu dalam memenuhi suatu kebutuhan. Kepercayaan individu atau masyarakat yang rendah akan berdampak terhadap rendahnya minat masyarakat dalam menggunakan suatu produk.

\section{Pengambilan Keputusan}

\section{LANDASAN TEORI}

Keputusan merupakan tahap akhir dalam menentukan tindakan seorang konsumen. Menurut Kusnadi (2015) pengambilan keputusan merupakan tindakan dalam pemilihan alternative. Keputusan merupaka suatu opsi dari beberapa pilihan yang dipertimbangkan. Menurut Kotler (Andini dkk,2014:2) dua situasi dapat menyebabkan pengambilan keputusan. situasi pertama adalah sikap orang lain, yaitu perilaku individu lain menurunkan pilihan favorite. situasi kedua yaitu situasi situasional yang diluar dugaan dimana bisa mengubah niat beli serta pada akhirnya membalikkan keputusan konsumen untuk membeli produk. Jika ini relevan dengan situasi saat ini, strategi viral marketing dapat mengubah keputusan guna menggunakan produk. Menurut Kotler dan Amstrong (2012) terdapat beberapa indikator dalam pengambilan keputusan yaitu pengenalan informative,pencarian informasi,evaluasi alternative, dan keputusan pembelian.

\section{Viral Marketing}

Viral merupakan suatu definsi yang sudah menjadi kata umum untuk diucapkan.Menurut James (2010:70) viral marketing merupakan metode pemasaran berbasis sistem. Penegasan pada makna virus yaitu guna menjelaskan informasi yang diberikan melalui sistem menyebar seperti virus, namun berdampak positif. Ananda (2019:21) mengemukakan Viral Marketing adalah metode marketing yang bertujuan memberikan infromasi kepada setiap konsumen dalam bentuk email atau video blog. Sehingga ditarik kesimpulan bahwa viral marketing merupakan strategi pemasaran produk dengan memanfaatkan internet sebagai media untuk menyalurkan informasi kepada konsumen. Menurut Kaplan dan Haenlein (2011) terdapat beberapa indikator yang digunakan untuk melihat viral marketing yaitu Sharing promo, notifikasi email, kolom komentar, keterlibatan pendapat pemimpin,keunggulan informasi produk dan pesan yang menarik.

\section{Kepercayaan Konsumen}

Kepercayaan adalah dasar dari hubungan transaksi bisnis antara pihak-pihak yang terkait. Kepercayaan harus terwujud mulai saat suatu pertemuan terjadi. Menurut Sumarwan (Sangadji dan Sopiah,2013:201),kepercayaan yaitu kemampuan suatu output mempunyai dampak terhadap kebutuhan suatu individu. Selain itu, Mowen dan Minor (Sangadji dan Sopiah,2013:201) 
mendefinisikan kepercayaan yaitu seluruh kesimpulan yang dibentuk konsumen. Berbeda dari pendapat diatas, Ba dan Pavlou (Priansa,2017:116) menngemukakan kepercayaan yaitu pengetahuan akan produk dalam melakukan suatu transaksi.Berdasarkan ketiga pendapat tersebut, dapat disimpulkan bahwa kepercayaan merupakan sebuah penilaian konsumen terhadap segala aspek serta manfaatnya untuk mengambil suatu keputusan. Menurut Wiludjeg (2013) terdapat beberapa indikator yang dapat dilakukan untuk mengukur kepercayaan konsumen diantaranya tampilan produk, informasi produk dan respon yang diberikan oleh penjual, serta rasa aman dalam berbelanja.

\section{METODE PENELITIAN}

\section{Metode Analisis}

Populasi pada penelitian ini yaitu seluruh mahasiswa aktif Program Studi Akuntansi Stambuk 2018 yang berjumlah 108 Mahasiswa. Penarikan jumlah sampel yang dipergunakan pada penelitian ini yaitu perhitungan Ferdinan (Fransisca dan Sugiyono,2014:5) jumlah sampel = Jumlah indikator dikali 5 sampai 10

Pada penelitian ini terdapat 13 indikator, maka jumlah sampel adalah: Sampel minimal $=5 \mathrm{x}$ $13=65$ Responden. Teknik menentukan sampel pada penelitian adalah random sampling dimana setiap anggota populasi memiliki peluang yang sama untuk menjadi sampel dalam penelitian. Pada penelitian ini memiliki teknik analisis data yaitu uji normalitas, linearitas, multikolinearitas, heteroskedastisitas dan analisis regresi linear berganda. Selain itu, sebelum angket disebarkan kepada responden terlebih dahulu dilakukan uji validitas dan reliabilitas untuk melihat kelayakan angket. Jenis data yang digunakan pada penelitian ini yaitu data primer.

\section{HASIL DAN PEMBAHASAN}

\section{Hasil dan Pembahasan}

Uji Normalitas

Uji normalitas yaitu pembuktian guna memeriksa nilai residue ternormalisasi pada model regresi berdistribusi normal. Pengujian bisa dilaksanakan dengan melalui analisis grafik probabilistik biasa. Dengan pendekatan ini, residual terdistribusi normal jika garis (titik) yang mewakili data aktual mengikuti atau mendekati diagonal. Selain pendekatan grafik apabila skor sig > 0,05 memiliki arti data berdistribusi dengan baik.

Tabel 1. Hasil Uji Normalitas

\begin{tabular}{|l|l|r|}
\hline \multicolumn{2}{|c|}{ One-Sample Kolmogorov-Smirnov Test } & Unstandardized Residual \\
\hline \multicolumn{2}{|c|}{$\mathrm{N}$} & 65 \\
\hline \multirow{2}{*}{ Normal Parameters ${ }^{\text {a,b }}$} & Mean & .0000000 \\
\cline { 2 - 3 } & Std. Deviation & 3.92077451 \\
\hline \multirow{2}{*}{ Most Extreme Differences } & Absolute & .095 \\
\cline { 2 - 3 } & Positive & .078 \\
\cline { 2 - 3 } & Negative & .095 \\
\hline \multicolumn{2}{|l|}{ Test Statistic } & .095 \\
\hline Asymp. Sig. (2-tailed) & $.2000^{c, d}$ \\
\hline a. Test distribution is Normal. & \\
\hline b. Calculated from data. & \\
\hline c. Lilliefors Significance Correction. & \\
\hline d. This is a lower bound of the true significance. & \\
\hline
\end{tabular}

482 | Boy Sitompul, Cristy Natalia Sembiring; The Influence of Viral Marketing... 
Berdasarkan output tabel 1. dihasilkan skor signifikansi $0,20>0,05$ sehingga diperoleh interpretasi nilai residue terdistribusi normal. Berdasarkan hasil uji dengan menggunakan analisis grafik plot diketahui bahwa Gabar 1. membentuk pola lurus yang mengikuti garis.

\section{Gambar 1. Normal Probability Plot}

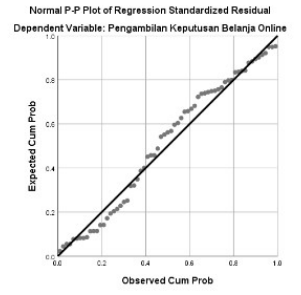

Uji Linearitas

Uji linearitas adalah uji hipotesis klasik guna melihat ada tidaknya linearitas variabel independen dengan variabel dependen serta skor sig > 0,05.

Tabel 2. Uji Linearitas Variabel Viral Marketing

\begin{tabular}{|c|c|c|c|c|c|c|c|}
\hline \multicolumn{8}{|c|}{ ANOVA Table } \\
\hline & & & $\begin{array}{l}\text { Sum of } \\
\text { Squares }\end{array}$ & Df & $\begin{array}{l}\text { Mean } \\
\text { Square }\end{array}$ & $\mathrm{F}$ & Sig. \\
\hline \multirow{5}{*}{$\begin{array}{l}\text { Pengambilan } \\
\text { Keputusan Belanja } \\
\text { Online * Viral } \\
\text { Marketing }\end{array}$} & \multirow{3}{*}{$\begin{array}{l}\text { Between } \\
\text { Groups }\end{array}$} & (Combined) & 363.290 & 13 & 27.945 & 1.641 & .105 \\
\hline & & Linearity & 40.696 & 1 & 40.696 & 2.389 & .128 \\
\hline & & $\begin{array}{l}\text { Deviation from } \\
\text { Linearity }\end{array}$ & 322.594 & 12 & 26.883 & 1.578 & .128 \\
\hline & \multicolumn{2}{|c|}{ Within Groups } & 868.766 & 51 & 17.035 & & \\
\hline & \multicolumn{2}{|l|}{ Total } & 1232.056 & 64 & & & \\
\hline
\end{tabular}

Berdasarkan output uji tabel 2. diketahui skor signifikan 0,128 $>0,05$ sehingga diperoleh interpretasi ada hubungan linear viral marketing terhadap pengambilan keputusan belanja di online shop pada mahasiswa Akuntansi Universitas Negeri Medan Stambuk 2018.

Tabel 3. Uji Linearitas Variabel Kepercayaan Konsumen

\begin{tabular}{|c|c|c|c|c|c|c|c|}
\hline \multicolumn{8}{|c|}{ ANOVA Table } \\
\hline & & & $\begin{array}{l}\text { Sum of } \\
\text { Squares }\end{array}$ & Df & $\begin{array}{l}\text { Mean } \\
\text { Square }\end{array}$ & $\mathrm{F}$ & Sig. \\
\hline \multirow{5}{*}{$\begin{array}{l}\text { Pengambilan } \\
\text { Keputusan Belanja } \\
\text { Online * } \\
\text { Kepercayaan } \\
\text { Konsumen }\end{array}$} & \multirow{3}{*}{$\begin{array}{l}\text { Between } \\
\text { Groups }\end{array}$} & (Combined) & 902.913 & 45 & 20.065 & 1.158 & .374 \\
\hline & & Linearity & 170.477 & 1 & 170.477 & 9.841 & .005 \\
\hline & & $\begin{array}{l}\text { Deviation from } \\
\text { Linearity }\end{array}$ & 732.436 & 44 & 16.646 & .961 & .561 \\
\hline & \multicolumn{2}{|c|}{ Within Groups } & 329.143 & 19 & 17.323 & & \\
\hline & \multicolumn{2}{|c|}{ Total } & 1232.056 & 64 & & & \\
\hline
\end{tabular}

Berdasarkan output uji tabel 3. ditemukan skor sig 0,561 >0,05 sehingga diperoleh interpretasi ada hubungan bersifat linear kepercayaan konsumen dengan pengambilan keputusan belanja di online shop pada mahasiswa Akuntansi Universitas Negeri Medan Stambuk 2018.

Uji Multikolinearitas

Uji multikolinearitas berfokus guna melihat korelasi model regresi antara variabel bebas dengan variabel terikat. Apabila diketahuhi bahwa ada korelasi yang tinggi antara variabel independen, bisa dikonfirmasi bahwa penelitian menunjukkan tanda-tanda multikolinearitas. 
Tabel 4. Uji Multikolinearitas

\begin{tabular}{|c|c|c|c|c|c|c|c|c|}
\hline \multicolumn{9}{|c|}{ Coefficients $^{a}$} \\
\hline & & \multicolumn{2}{|c|}{$\begin{array}{c}\text { Unstandardized } \\
\text { Coefficients }\end{array}$} & \multirow{2}{*}{$\begin{array}{c}\begin{array}{c}\text { Standardize } \\
\mathrm{d}\end{array} \\
\text { Coefficients } \\
\text { Beta } \\
\end{array}$} & \multirow[b]{2}{*}{$\mathrm{t}$} & \multirow[b]{2}{*}{ Sig. } & \multicolumn{2}{|c|}{$\begin{array}{c}\text { Collinearity } \\
\text { Statistics }\end{array}$} \\
\hline \multicolumn{2}{|c|}{ Model } & B & Std. Error & & & & $\begin{array}{c}\text { Toleranc } \\
\text { e }\end{array}$ & VIF \\
\hline \multirow[t]{3}{*}{1} & (Constant) & 20.512 & 3.254 & & 6.304 & .000 & & \\
\hline & Viral Marketing & -.251 & .113 & -.255 & -2.213 & .031 & .969 & 1.032 \\
\hline & $\begin{array}{l}\text { Kepercayaan } \\
\text { Konsumen }\end{array}$ & .544 & .151 & .417 & 3.616 & .001 & .969 & 1.032 \\
\hline
\end{tabular}

Berdasarkan hasil uji multikolinearitas ditemukan toleransi 0,969 > 0,10 serta VIF 1,032 < 10 . Menurut output 4. diperoleh suatu interpretasi bahwa tidak adanya gejala multikolinearitas variabel independen dengan variabel dependen.

Uji Heteroskedastisitas

Heteroskedastisitas yaitu uji asumsi yang dipergunakan guna mengetahui penyimpangan asumsi klasik. Ketentuan model regresi adalah tidak adanya tanda-tanda heteroskedastisitas variabel.

Tabel 5. Uji Heteroskedastisitas

\begin{tabular}{|c|c|c|c|c|c|c|c|c|}
\hline \multicolumn{9}{|c|}{ Coefficients $^{a}$} \\
\hline & & \multicolumn{2}{|c|}{$\begin{array}{l}\text { Unstandardized } \\
\text { Coefficients }\end{array}$} & \multirow{2}{*}{$\begin{array}{c}\begin{array}{c}\text { Standardize } \\
\text { d }\end{array} \\
\text { Coefficients } \\
\text { Beta }\end{array}$} & \multirow[b]{2}{*}{$\mathrm{T}$} & \multirow[b]{2}{*}{ Sig. } & \multicolumn{2}{|c|}{$\begin{array}{c}\text { Collinearity } \\
\text { Statistics }\end{array}$} \\
\hline \multicolumn{2}{|c|}{ Model } & B & Std. Error & & & & $\begin{array}{c}\text { Toleranc } \\
\text { e }\end{array}$ & VIF \\
\hline \multirow[t]{3}{*}{1} & (Constant) & 6.848 & 1.581 & & 4.333 & .000 & & \\
\hline & Viral Marketing & -.054 & .055 & -.121 & -.974 & .334 & .969 & 1.032 \\
\hline & $\begin{array}{l}\text { Kepercayaan } \\
\text { Konsumen }\end{array}$ & -.133 & .073 & -.225 & -1.813 & .075 & .969 & 1.032 \\
\hline
\end{tabular}

Berdasarkan output tabel 5. nilai signifikan X1 adalah 0,334 $>0,05$ dan X2 adalah 0,075 $>0,05$ sehingga dapat diambil kesimpulan tidak terrdapat gejala heteroskedastisitas.

\section{PEMBAHASAN}

Uji Hipotesis Parsial (Uji T)

Uji t merupakan pengujian guna menemukan dampak variabel independen terhadap variabel dependen. Berdasarkan hasil pengujian tabel 6. ditemukan skor sig variabel viral marketing (X1) adalah 0,031<0,05 serta variabel kepercayaan konsumen $(X 2)$ adalah 0,001<0,05. Dapat ditarik kesimpulan bahwa variabel viral marketing dan kepercayaan konsumen masing-masing memiliki pengaruh pada pengambilan keputusan belanja di online shop. 
Tabel 6. Hasl Uji

\begin{tabular}{|c|c|c|c|c|c|c|}
\hline \multicolumn{7}{|c|}{ Coefficients $^{a}$} \\
\hline & & \multicolumn{2}{|c|}{ Unstandardized Coefficients } & \multirow{2}{*}{$\begin{array}{c}\text { Standardized } \\
\text { Coefficients } \\
\text { Beta }\end{array}$} & \multirow[b]{2}{*}{ T } & \multirow[b]{2}{*}{ Sig. } \\
\hline \multicolumn{2}{|c|}{ Model } & B & Std. Error & & & \\
\hline \multirow[t]{3}{*}{1} & (Constant) & 20.512 & 3.254 & & 6.304 & .000 \\
\hline & Viral Marketing & -.251 & .113 & .255 & -2.213 & .031 \\
\hline & Kepercayaan Konsumen & .544 & .151 & .417 & 3.616 & .001 \\
\hline
\end{tabular}

Uji Hipotesis Secara Simultan (Uji F)

Uji F yatu uji yang dilaksanakan guna menemukan dampak seluruh variabel X1 dan X2 secara bersama-sama berpengaruh kepada Y.Berdasarkan hasil tabel 7. ditemukan persamaan regresi $\mathrm{Y}=20.512-0,251 \mathrm{X} 1+0,544 \mathrm{X} 2$. Diketahui nilai $F_{\text {tabel }}$ adalah $7,821>2,76$ dan skor sig $0,001<0,05$ sehingga diperoleh interpretasi terdapat dampak secara simultan variabel viral marketing dan kepercayaan konsumen pada pengambilan keputusan berbelanja online shop mahasiswa Akuntansi Universitas Negeri Medan Stambuk 2018.

Tabel 7. Hasil Uji Simultan

\begin{tabular}{|c|c|c|c|c|c|c|}
\hline \multicolumn{7}{|c|}{ ANOVA $^{a}$} \\
\hline \multicolumn{2}{|c|}{ Model } & Sum of Squares & Df & Mean Square & $\mathrm{F}$ & Sig. \\
\hline \multirow[t]{3}{*}{1} & Regression & 248.218 & 2 & 124.109 & 7.821 & $.001^{b}$ \\
\hline & Residual & 983.838 & 62 & 15.868 & & \\
\hline & Total & 1232.056 & 64 & & & \\
\hline
\end{tabular}

\section{Koefisien Determinasi}

Uji $R$ Square adalah pengujian dengan melihat dampak variabel bebas secara bersama-sama terhadap variabel terikat. Berdasarkan hasil output pengolahan SPSS di atas, diperoleh nilai $r$ square yaitu 0,201 atau $25,1 \%$. Sehingga memiliki makna variabel bebas memiliki pengaruh sebesar $25,1 \%$ terhadap pengambilan keputusan berbelanja di online shop sedangkan $74,9 \%$ lagi merupakan faktor lain yang tidak diteliti.

Tabel 8. Koefisien Determinasi

\begin{tabular}{|l|r|r|r|r|}
\hline \multicolumn{5}{|c|}{ Model Summary } \\
\hline Model & $\mathrm{R}$ & R Square & Adjusted R Square & Std. Error of the Estimate \\
\hline 1 & \multicolumn{2}{|c|}{$.449^{a}$} & .251 & .176 \\
\hline
\end{tabular}

\section{KESIMPULAN}

Kesimpulan

1. Variabel viral marketing berdampak positif dan signifikan pada pengambilan keputusan belanja online shop mahasiswa Akuntansi Universitas Negeri Medan Stambuk 2018.

2. Variabel kepercayaan konsumen berdampak positif dan signifikan pada pengambilan keputusan belanja online shop mahasiswa Akuntansi Universitas Negeri Medan Stambuk 2018. 
3. Variabel viral marketing dan kepercayaan konsumen berdampak positif serta signifikan secara simultan terhadap pengambilan keputusan belanja online shop mahasiswa Akuntansi Universitas Negeri Medan Stambuk 2018.

4. Variabel viral marketing dan kepercayaan konsumen mempunyai dampak senilai $25,1 \%$ terhadap pengambilan keputusan belanja di online shop pada mahasiswa Akuntansi Universitas Negeri Medan Stambuk 2018

\section{DAFTAR PUSTAKA}

Ananda, Silvia.2019.Pengaruh Viral Marketing Dan Kepercayaan Pelanggan Terhadap Keputusan Pembelian Online Shop Berbasis Aplikasi Pada Mahasiswa/l Fakultas Ekonomi Dan Bisnis Universitas Sumatera Utara.Skripsi FEB USU.

Andini et al.2014.Pengaruh Viral Marketing Terhadap Kepercayaan Pelanggan Dan Keputusan Pembelian (Studi Pada Mahasiswa Fakultas IImu Administrasi Universitas Brawijaya Angkatan 2013 yang Melakukan Pembelian Online Melalui Media Sosial Instagram). https://media.neliti.com/media/publications/82726-ID-pengaruh-viral-marketing-terhadapkeperc.pdf (di akses pada 09 September 2021).

Anwar,Herson.2014, Proses Pengambilan Keputusan untuk Mengembangkan Mutu Madrasah. Jurnal Pendidikan Islam, Vol. 8, No. 1.

Badan Kajian Kebijakan dan Inovasi Administrasi Negara.2018.Procesing Data Penelitian Kuantitatif dengan Menggunakan Eviews.Modul Pusat Kajian dan Pendidikan dan Pelatihan Aparatur IV Lembaga Administrasi Negara. http://aceh.lan.go.id/wp-content/uploads/2018/10/ModulEviews-.pdf (di akses pada September 2021).

Badan Pusat Statistik (BPS).2020. Statistik E-COMMERCE 2020. https://www.bps.go.id/publication/2020/12/24/2548417ddc6dab8247553124/statistik-ecommerce-2020.html (di akses pada 09 September 2021).

Frasisca,Happy dan Sugiyono.2014. Perspektif Konsumen Terhadap Retail Mix Di Ayam Bakar Primarasa Ahmad Yani Surabaya. https://media.neliti.com/media/publications/132069-IDperspektif-konsumen-terhadap-ritel-mix-d.pdf (di akses pada 8 September 2021).

Harahap, Dedy Ansari dan Dita Amanah.2018. Perilaku Belanja Online Di Indonesia: Studi Kasus. http://journal.unj.ac.id/unj/index.php/jrmsi/article/view/6005/5876 (di akses pada 09 September 2021).

Ishak, A., dan Luthfi, Z., (2011), Pengaruh Kepuasan dan Kepercayaan Konsumen Terhadap Loyalitas: Studi Tentang Peran Mediasi Switching Costs, Jurnal Siasat Bisnis, Vol. 15, No. 1.

Kaplan, A. M., \& Haenlein, M. 2011. User Of The World, Unite! The UNIVERSITAS SUMATERA UTARA Challenges nd Opportunities Of Social Media. Elsevier, 53(1), 59-69.

Kusnadi,Dedel.2015. Pengambilan Keputusan Dalam Perilaku Organisasi. Jurnal IImiah Universitas Batanghari Jambi, Vol. 15, No. 2.

Pramiyati et al .2017.Peran Data Primer Pada Pembentukan Skema Konseptual Yang Faktual (Studi Kasus: Skema Konseptual Basis data Simbumil). https://jurnal.umk.ac.id/index.php/simet/article/view/1574/1121 (di akses pada 8 September 2021)

Priansa,Donni Juni.2017.Perilaku Konsumen dalam Persaingan Bisnis Kontemporer.Bandung:ALFABE.

Sangadji, Etta Mamang dan Sopiah.2013.Peilaku Konsumen Pendekatan Praktis Disertai Himpunan Jurnal Penelitian.Yogyakarta:ANDI.

Sari,Chaca Adinda.2015. Perilaku Berbelanja Online Di Kalangan Mahasiswi Antropologi Universitas Airlangga.Jurnal AntroUnairdotNet (http://www.journal.unair.ac.id/download-fullpapersauna97cbdaabbfull.pdf).

Sari,Ratna Kartika.2019.Viral Marketing:Memanfaatkan kekuatan Media Sosial Dalam Komunikasi Pemasaran. https://unars.ac.id/ojs/index.php/cermin_unars/article/view/488/408 (di akses pada 09 September 2021).

486 | Boy Sitompul, Cristy Natalia Sembiring; The Influence of Viral Marketing... 
Setiyaningsih, Dewi Nur dan D Koeshatono.2014. Pengaruh Kepuasan Dan Kepercayaan Konsumen Terhadap Loyalitas Konsumen Dengan Switching Cost Sebagai Variabel Mediasi. http://ejournal.uajy.ac.id/6094/1/Jurnal\%20EM18057.pdf (di akses 09 September 2021).

Situmorang,James R. 2010.Pemasaran Viral - Viral Marketing. Jurusan IImu Administrasi Bisnis,Vol. 6, No 1.

Wiludjeng, S. 2013. Pengaruh Viral Marketing Terhadap Keputusan Pembelian Pada PT "X". Skripsi. Bandung : Universitas Widyatama. 